\title{
EVALUATION OF EFFICIENCY IN SECONDARY EDUCATION
}

\author{
Daniela Mališová ${ }^{1}$ \\ Jana Štrangfeldová 2
}

DOI: https://doi.org/10.31410/LIMEN.S.P.2020.111

\begin{abstract}
The state of Slovak education is influenced by several negative factors. In terms of human capital, we have seen the decline of pupils for demographic reasons and lack of interest in the work of teachers. This paper aims to evaluate the efficiency of secondary education on the example of selected secondary schools. The main method of the paper is multicriteria analysis. The subject of research is the efficiency of selected secondary schools. The 10 Business Academies attended by pupils aged 15-19 years and established in the Banska Bystrica and Žilina self-governing regions will be the subject of research. For the analysis we use panel data collected for the school years 2013/2014 - 2017/2018. The contribution of the paper is to create an evaluation of the efficiency of the surveyed schools and to propose solutions for schools that achieved below-average results. The findings may serve as a basis for assessing the efficiency of the Business Academies for comparison with competitors, as well as for the founders of these secondary schools.
\end{abstract}

Keywords: Efficiency, Education, Business academy, Self-governing region.

\section{INTRODUCTION}

$\mathrm{E}$ ducation is seen as a significant determinant of human capital development. Human capital can be identified with acquired schooling and viewed as a determinant of economic growth, along with basic production factors (Gould, Ruffin, 1995; Gillies, 2015). According to research, we find out that in Slovakia, the share of secondary school educated people is $60 \%$ (Lauko, Gruňák, Križan, Tolmáči, 2012). The emphasis on education should therefore be on secondary education. Several authors (Afonso, St. Aubyn, 2004; Koróny, Hronec, 2012) have studied the efficiency of secondary schools and education systems. Based on efficiency, some rankings help schools and their founders improve their performance. Also, these results can affect students' choices when choosing a school institution for further study.

\section{THEORETICAL BACKGROUND OF EFFICIENCY IN EDUCATION}

The Slovak Republic has the right to education given in the basic legal document - the Constitution. The task of education is to build a system of knowledge, habits, skills and values, physical and mental abilities. Educating and teaching the population supports their skills, disrupts passivity and generates higher incomes (Dembélé, Lefoka, 2007). In terms of human capital, the content of education at secondary schools is the development of individual, integration, regulatory and knowledge potential. Secondary education prepares for the practical exercise of the profession. Education should constitute the intersection of theoretical and practical learning, as well as career preparation and contextual learning (Lynch, 2000). One of

\footnotetext{
${ }^{1}$ Faculty of Economics, Matej Bel University, Tajovského 1097590 Banská Bystrica, Slovak Republic

${ }^{2}$ Faculty of Economics, Matej Bel University, Tajovského 1097590 Banská Bystrica, Slovak Republic
} 
the goals of the current education reform - Learning Slovakia (Burjan, Ftáčnik, Juráš, et al., 2017 ) is the cross-curricular interconnection of knowledge, which we rate positively. Providers of secondary education in Slovakia are self-governing regions, which perform this task within the scope of the transferred competence of the state.

However, there is an opinion that education should not be provided by the state because of its inadequacy. From the literature review we know, that few researchers (Mauro, Sedano, 2005) state that education should be provided by other structures, with freedom, hope and all-round development prevailing. We are critical of this view because there would be exclusion and rivalry in the private provision of education alone. Consequently, low-income social groups would not be able to participate. Compulsory schooling, which lasts 10 years, also applies in Slovakia. The last year is the content of secondary education.

The research assumption is to find out what level of efficiency the researched Business Academies achieve. These secondary schools are attended by pupils aged 15-19. The Business Academy curriculum complies with ISCED-3A, implemented during four years of study and focusing on vocational training for economic, business, marketing, monetary activities and tourism work of Business Academies (Šlosarová, 2002). We use quantitative and qualitative indicators to investigate research assumptions. The efficiency study aims to compare inputs with outputs. In the absence of data, we replace missing indicator values with the lowest measured value of the corresponding indicator each year. From an economic point of view (Palmer, Torgerson, 1999), achieving greater output efficiency at specified resources should be the main criterion for prioritizing schools.

Figure 1. Development of the Average Age of Teaching Staff in 8 Business Academies in monitored periods

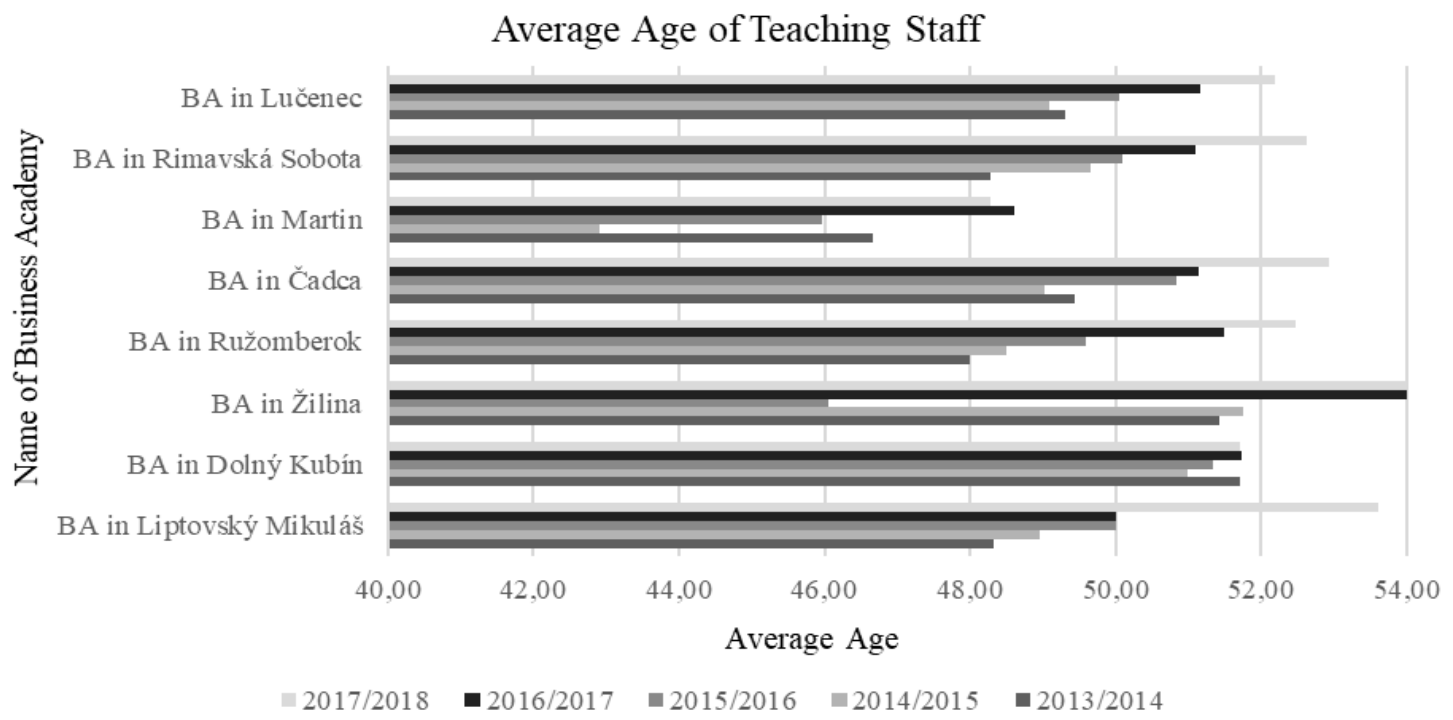

Source: own processing based on Internal Reports (2020)

We reflect on the current situation when the number of teachers is falling due to a lack of interest in this profession. The reason is the unfavorable situation caused by the employment of retired teachers, which results in a low number of vacancies in this sector in the labor market, and thus a lack of interest in the profession (Beňp, Šimčáková, 2007). The qualified teaching staff is the main condition for the functioning and development of the educational system. It is precisely the influence of this factor that we monitor in the age average indicator of the teaching staff. 
We excluded BA in Brezno and BA in Banská Bystrica from observation (Figure 1) because they did not disclose their data. We find that the average age of the teaching staff in the last reference year is 52 years. The biggest change was recorded in BA in Žilina, when the average age increased by $17.3 \%$ (SE 2.59\%). This BA employed 7 teachers under 60 years old; 2 teachers over 60 years old and 7 retired teachers, as an example of the above situation. The opposite effect is observed in BA in Martin. The average age in the school year 2017/2018 is 48.2 years and $63.6 \%$ (SE 9.57\%) of teachers are under 50 years old, which we consider being younger productive age.

The formation of human capital concerns pupils. From the overall development, we find that during the monitored periods the attendance of selected secondary schools decreased by $31.72 \%$ (SE 4.76\%), which can be calculated as a total decrease of 100 pupils per year. The decline is also associated with a decline in open classes, but especially a decrease in income from normative funding. Funds resulting from normative funding per pupil increase by approximately $2 \%$ per year and amounted to 42.84 EUR for the 2017/2018 school year. Thus, as the number of pupils decreases, so does the public finance. Schools are therefore forced to use other resources to improve their financial situation. The most common are projects and grants provided by the European Union, or business activities (rental of premises, etc.).

\section{METHODOLOGY AND METHODS OF RESEARCH}

This paper aims to evaluate the efficiency of secondary education on the example of selected secondary schools. From the methodological point of view, the work is divided into 4 stages. In the first stage, primary research was carried out to identify suitable indicators to measure efficiency. The research was carried out by a method of semi-structured interview with the professional public, consisting of directors, representatives, economic workers and former graduates of selected secondary schools. The semi-structured interview method (Miovský, 2006; Kallio, Pietilä, Johnson, 2016) focuses on qualitative research. It is important to discuss the questions of the conversation and should be based on data or facts. Efficiency indicators have been compiled according to the research of qualitative indicators of education (Štefanišinová, Štrangfeldová, 2020). The discussions were conducted following ethical principles. Based on the outcome of the interviews, we select the 4 most rated indicators.

In the second phase of the research, panel data for the school years 2013/2014 - 2017/2018 were compiled. Financial Statements, Internal Reports and Annual Evaluation of secondary schools served as data collection materials. Please note that BA in Banská Bystrica has no data available for the school years 2013/2014 and 2015/2016, BA in Brezno has not made available data for the school years 2013/2014 - 2015/2016 and BA in Žilina has not made data available for the school year 2017/2018. This may be due to slightly biased results or disproportionately high statistical error. However, it was not possible to abstract from these academies, as they are established by a self-governing region for a comprehensive expression of efficiency measuring the self-governing regions and their comparison.

In the third stage, we determine the efficiency of the monitored secondary schools using the standardized variable and integral indicator method. Multicriteria analysis (Skubičan, 2010) is a tool that greatly facilitates the decision-making process. The advantage of the method is that we can use an unlimited number of input and output indicators. In the standard variable method, the original values of the individual variables are converted to a dimensionless number. In the first step we calculate simple arithmetic means $\left(\mathrm{x}_{\mathrm{j}}\right)$, standard deviations $\left(\mathrm{s}_{\mathrm{xj}}\right)$ for each indicator. Subsequently, we subtract the arithmetic mean from the original values and divide their 
difference by the standard deviation. In the case of indicators with the aim of minimizing, on the contrary, the value is deducted from the arithmetic mean and subsequently the difference divided by the standard deviation (Jenčová, 2011). Mathematical expression:

$$
u_{i j}=\frac{\left(x_{i j}-x_{\text {priemj }}\right)}{s_{x j}} \quad u_{i j}=\frac{\left(x_{\text {priem }}-x_{i j}\right)}{s_{x j}}
$$

Where:

$\mathrm{x}_{\mathrm{ij}}$ - the value of the $\mathrm{j}$-th indicator in the $\mathrm{i}$-th subject;

$\mathrm{x}_{\text {priemj }}$ - arithmetic mean calculated from the values of the $\mathrm{j}$-th indicator;

$\mathrm{s}_{\mathrm{xj}}$ - standard deviation, calculated from the values of the $\mathrm{j}$-th indicator.

The mathematical expression of integral indicator (Sabol, Tkáč, 2012) is given according to the formula:

$$
d_{i}=\frac{\sum_{i=1}^{m} u_{i j} * p_{j}}{\sum_{i=1}^{m} p_{j}}
$$

Where:

$u_{i j}$ - the value of the $j$-th indicator in the $i$-th subject,

$p_{j}-$ the weight of $j$-th indicator.

The best subject is one whose integral indicator is maximum. The advantage of the method is the variability of the indicator. The method evaluates the degree of fulfillment of the set criteria in periods, taking into account their importance through weights (Štrangfeldová, 2013). For efficiency, we set weights as 10:9:11:10. Weights are used to score individual indicators found in the first phase of the research.

In the fourth stage, we interpret the results, using the statistical method of data sorting. At the end of the research, we propose suitable solutions for improving the efficiency of the monitored academies.

\section{RESULTS AND DISCUSSION}

The result of the first stage of the research (Figure 2) is the compilation of appropriate qualitative and quantitative indicators based on the semi-structured interview method. Based on the points obtained, the weight of the indicator for the efficiency measurement was determined.

In the next phase of the research, we will work with the quantitative indicators of the average number of pupils per class and the average number of pupils per teacher. Qualitative indicators are the average age of the teaching staff and academic achievement. The interviews confirmed that the average age of the teaching staff indicator is important. This is because a high proportion of older teachers is associated with a higher absence for health reasons. And, according to the addressed director, older teachers do not respond flexibly to current changes, they are not interested in engaging in projects that are in cooperation with abroad because of a lack of language skills. The motivation of university-educated people is precisely the expectation of higher wages in the future (Čarnogurská, 2019). This is also confirmed by the results of the interviews; the low wage in the field does not sufficiently motivate young people 
to work in the field of education, even if they have graduated from the pedagogical direction of higher education.

Figure 2. Appropriate indicators for measuring efficiency according to professional public (in points)

\section{Qualitative and Quantitative Indicators}

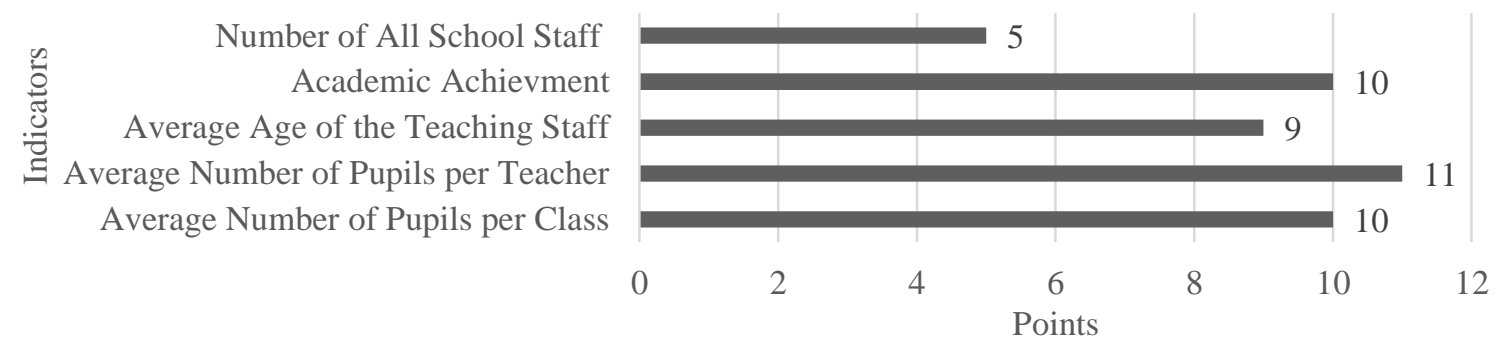

Source: own processing (2020)

Table 1 below shows the overall value of the integral performance indicator of efficiency. The best use of inputs at the output shows the academy, whose integral indicator reaches the maximum level. Interpretation of results is complemented by recommendations for improving efficiency. Recommendations for improvement of quantitative indicators are formulated based on the best result in the given part of the file. We use the law (Act No. 464/2013 Coll.) to formulate recommendations for qualitative indicators. The efficiency of the monitored secondary schools in the Žilina self-governing region is expressed by a decreasing curve. The best average result was achieved in the school year 2013/2014.

Table 1. Efficiency of 10 Business Academies in the monitored periods

\begin{tabular}{|l|r|r|r|r|r|r|}
\hline \multicolumn{7}{|c|}{ Žilina self-governing region } \\
\hline $\begin{array}{c}\text { Name of Academy / } \\
\text { School Year }\end{array}$ & $2013 / 2014$ & $2014 / 2015$ & $2015 / 2016$ & $2016 / 2017$ & $2017 / 2018$ & Average \\
\hline BA in Liptovký Mikulás & -0.216 & -0.774 & -1.176 & -1.122 & -0.892 & -0.836 \\
\hline BA in Dolný Kubín & 0.022 & 0.473 & 0.268 & -0.063 & 0.919 & 0.323 \\
\hline BA in Žilina & 0.055 & 0.176 & 0.600 & 0.255 & -1.282 & -0.039 \\
\hline BA in Ružomberok & -0.257 & -0.259 & 0.156 & 0.058 & -0.404 & -0.141 \\
\hline BA in Čadca & 0.764 & 0.428 & 0.049 & 0.400 & 0.167 & 0.362 \\
\hline BA in Martin & -0.368 & -0.043 & 0.103 & 0.472 & 0.523 & 0.137 \\
\hline \multicolumn{7}{|c|}{ Banská Bystrica self-governing region } \\
\hline Name of Academy / \\
School Year & $2013 / 2014$ & $2014 / 2015$ & $2015 / 2016$ & $2016 / 2017$ & $2017 / 2018$ & Average \\
\hline BA in Banská Bystrica & -0.707 & -0.058 & -0.707 & 0.236 & -0.010 & -0.249 \\
\hline BA in Brezno & -0.707 & -0.667 & -0.707 & -0.566 & -0.429 & -0.615 \\
\hline BA in Rimavská Sobota & -0.389 & -0.586 & -0.354 & -0.294 & -0.646 & -0.454 \\
\hline BA in Lučenec & 0.389 & 0.484 & 0.354 & 0.306 & 0.470 & 0.401 \\
\hline
\end{tabular}

Source: own processing (2020)

We are seeing a big slack between the maximum and minimum efficiency levels even today. In this self-governing region, the best efficiency was achieved in BA in Cadca. Nevertheless, we observe that its efficiency decreased on average by $31.6 \%$ (SE 4.74\%) over the period. This academy should therefore respond to a change in the number of pupils by reducing classes by 2, achieving an 18\% (SE 1.26\%) better efficiency. Most teachers (i.e. 20) are under the working 
age of up to 50. On average, BA in Dolný Kubín ranked second. In the last reporting period, there has been a significant increase in efficiency. This is due to the low age average of the teaching staff (i.e. 51.72 y.o.), the excellent academic achievement (i.e. 1.75) as well as the high average number of pupils in the class (i.e. 25.08).

The results oscillating around the average recorded 3 academies. The reason for the significant slippage of BA in Žilina is the use of the lowest measured data for individual indicators. Based on the data in 2016/2017, we propose to increase the number of pupils by 9 (i.e. 413), when the academy reaches the required average value of 25 pupils per class and at the same time the value of 11.47 average pupils per teacher. As a result, efficiency will increase to $27.7 \%$ (SE 4.16\%). We recommend adjusting the academic achievement to 1.93 (the best value in the file). An average result was also achieved by BA in Martin. This academy has the lowest age average of the teaching staff (i.e. 48.28 y.o.). In order to improve the efficiency result, we propose to increase the number of pupils by 23 (i.e. 325) pupils in the following school year, the overall efficiency is $50 \%$ better.

Under average results were achieved by the smallest Business Academies by capacity. BA in Ružomberok the best efficiency result was recorded by the academy in the school year 2015/2016. To achieve this result, we recommend reviewing the need for 2 retired teachers or optimizing the average number of pupils in the class by reducing the number of classes to 8. Under these circumstances, overall efficiency would increase to $17.3 \%$. In another way, the lowest overall result was achieved by BA in Liptovský Mikuláš. We observe a decrease in the value of efficiency during school years by an average of $32.40 \%$ per year (SE $4.86 \%$ ). In the school year 2017/2018, this is a slight increase due to an improvement in academic achievement (i.e. 2,02) and an increase in the average number of pupils in the class $($ i.e. 21,14$)$ and a decrease in the number of teachers in retirement age.

What more, BA in Liptovský Mikuláš shows an overall disparity of indicators. It employs an equal number of teachers like BA in Ružomberok, with only 148 students attending it. Therefore, we propose to reduce the number of classes to 6 , increasing the average number of pupils in the class to 24.6 and reducing the number of teachers by up to 9 people, increasing the average number of pupils per teacher to the recommended value of 12 pupils. These measures achieve an overall efficiency of 0.483 (SE 0.097), which significantly improves the efficiency result. If the academy wanted to increase the number of pupils, it would have to apply the same measures as the previous BA in Ružomberok.

In the second part of the sample we follow the development of efficiency in the Banská Bystrica self-governing region. The curve reflecting this trend is slightly increasing in nature but is still relatively low. The average annual change is $18.78 \%$ (SE $2.81 \%$ ). BA in Lučenec shows the best long-term efficiency. The highest achieved academic value was in the school year 2014/2015 (i.e. 48.4\%). Thanks to the highest average number of pupils in the class (i.e. 27.13) and the low average age of the teaching staff (i.e. 52.20 y.o.) achieved an efficiency of 47\% (SE 7.05\%) in the school year 2017/2018. Other academies in the group show significantly lower efficiency results.

In comparison with similar research (Štrangfeldová, Štefanišinová, Hronec, et al., 2018) focused on the evaluation of the quality of Grammar schools in the Banská Bystrica selfgoverning region, we find that the Business Academies we studied have achieved significantly worse results than another type of schools (Grammar schools). An exception is just BA in Lučenec, which like Grammar school B.S.T. Lučenec achieved positive values of efficiency. 
Thus, this academy can serve as a benchmark for comparison with other academies in the selfgoverning region.

BA in Banská Bystrica achieved an average efficiency result of the Banská Bystrica selfgoverning region. Nevertheless, this is a relatively low value in relation to BA in Lučenec. In the last two years, we have been using real data for the academy. The number of pupils decreased by 100 during the period under review. To improve the outcome, we recommend increasing the number of pupils by 19 to achieve the recommended average number of pupils per teacher, with a total efficiency of $11.9 \%$ (SE 1.43\%).

BA in Rimavská Sobota achieved the lowest efficiency result in the school year 2017/2018. This is due to the low value of the academic achievement indicator (i.e. 2.20), the low number of pupils per teacher (i.e. 23.88) and the high age average of the teaching staff. Only 5 teachers are of younger productive age, the remaining 14 are over 50 years and 2 are of retirement age. To increase efficiency by $59 \%$ (SE 11.80\%), we propose to increase the number of pupils by 9 (i.e. 200). This is a relatively achievable alternative, given the capacity of the academy in previous years.

Despite the low-efficiency result, BA in Brezno shows the ideal average number of pupils in a class. The average number of pupils per teacher is only 3.85 pupils. Therefore, we propose to reduce the number of teachers by 18 , thus achieving an average number of pupils per teacher at the required level. This is a significant rationalization measure, but since the academy works together with another secondary school-related in subjects, we recommend the possibility of interconnecting these institutions and creating a part-time job. With this measure, the academy would show $40.6 \%$ (SE 6.09\%) efficiency. When increasing the number of pupils, the academy would have to achieve fullness as BA in Banská Bystrica (i.e. 325 pupils). However, such a measure is not realistic.

\section{CONCLUSION}

The development of human capital is strongly influenced by acquired education. Therefore, we focus our research on the field of secondary education, which is completed by the majority of Slovak citizens. This paper aims to evaluate the efficiency of secondary education on the example of selected secondary schools. We monitor efficiency during 5 school years at 10 Business Academies established in Banská Bystrica and Žilina self-governing regions. The main method of the paper is multicriteria analysis.

In Žilina the self-governing region achieves above the average result of efficiency BA in Čadca. This academy shows $36.2 \%$ efficiency. Most teachers are at a younger productive age. The average age of the teaching staff has proven to be a significant determinant of the efficiency outcome. BA in Dolný Kubín achieved second-best rank - just by 10.78\% (SE 1.58\%) lower efficiency result than BA in Čadca. BA in Lučenec achieved the best result in the Banská Bystrica self-governing region. The efficiency of this academy is $40.1 \%$. Qualitative and quantitative indicators reached very good values. This academy can serve as a benchmark for the other academies studied. Average results were achieved in BA in Žilina, BA in Martin, BA in Ružomberok and BA in Banská Bystrica. For these academies, we formulate recommendations for improving efficiency by changing the monitored indicators. BA in Liptovský Mikuláš, BA in Rimavská Sobota and BA in Brezno show low values of efficiency. In order to improve the efficiency value, it is necessary to make more significant corrections. 
In conclusion, we state that we managed to verify the research assumption. We found out what level of efficiency the researched Business Academies achieve. Please also note that the measurement of the efficiency of secondary schools was carried out based on indicators that the professional public described as appropriate, valuable and meaningful. The use of a different combination of indicators may result in differences in the overall performance results of secondary schools.

\section{ACKNOWLEDGEMENTS}

This paper is part of the project VEGA 1/0334/19 Evaluating the performance of regional education by the value-for-money method, using the example of grammar schools.

\section{REFERENCES}

Act No. 464/2013 Coll., which supplements and amends Act No. 245/2008 Coll. on upbringing and education. Ministry of education, science, research and sport of the Slovak republic. \$29. Retrieved from https://www.slov-lex.sk/pravnepredpisy/SK/ZZ/2013/464/20160901

Afonso, A., St. Aubyn, M. (2004) Non- Parametric Approaches to Education and Health Efficiency in OECD Countries. ISEG-UTL Economics Working Paper. 1-34 p.

Beňo. M., Šimčáková. L. (2007) Analyticko-prognostické štúdie o regionálnom školstve SR 2007. ( $1^{\text {st }}$. ed.) Bratislava: Ústav informácií a prognóz školstva.

Burjan, V. Ftáčnik, M. Juráš, I. et al. (2017) Učiace sa Slovensko. Ministry of education, science, research and sport of the Slovak republic. pp. 113 - 118. Retrieved from https://www.minedu.sk/data/files/6987_uciace_sa_slovensko.pdf

Čarnogurská, Z. (2019) Hodnotenie výskytu nadmernej kvalifikácie na slovenskom trhu práce. Ekonomika a spoločnost'. 20(1), pp. 15 - 24.

Dembélé. M., Lefoka. P. (2007) Pedagogical Renewal for Quality Universal Primary Education: Overview of Trends in Sub-Saharan Africa. International Review of Education. 53(5-6) pp. 531-553.

Gillies, D. (2015) Human Capital Theory in Education. In Peters, M. (Ed.) Encyclopedia of Educational Philosophy and Theory. (1 ${ }^{\text {st }}$. ed., pp. 571-583). Singapore: Springer.

Gould, D. M., Ruffin, R. J. (1995) Human Capital, Trade and Economic Growth. Review of World Economics. 131(3), pp. 425-445.

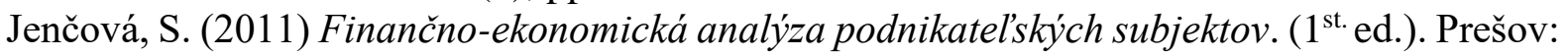
Grafotlač.

Kallio, H., Pietilä, M.-A., Johnson, M. et al. (2016) Systematic methodological review: developing a framework for a qualitative semi-structured interview guide. Journal of Advanced Nursing. 72(12), pp. 2954-2965.

Koróny, S., Hronec, Š. (2012) DEA analýza efektívnosti úrovne vedy a techniky verejných vysokých škôl na Slovensku. Forum Statisticum Slovakum. 2012(4). pp. 117-125.

Lauko. V., Gurňák. D., Križan. F., Tolmáči. L. (2012) Najnovšie vývojové trendy vzdelanostnej štruktúry obyvatel'stva Slovenska v časovo-priestorových súvislostiach. Geographia Cassovienses. 6(2), pp. 91 - 102.

Lisý, J. (2011) Ekonómia. (1 ${ }^{\text {st }}$ ed.) Bratislava: Iura Edition.

Lynch, R. (2000) High School Career and Technical Education for the First Decade of the 21st Century. Journal of Vocational Education Research. 25(2), pp. 155-198.

Mauro. M., Sedano. R. A. (2005) Educación: una cuestión de libertad. Estudios sobre Educación. 8(7), pp. 7-30. 


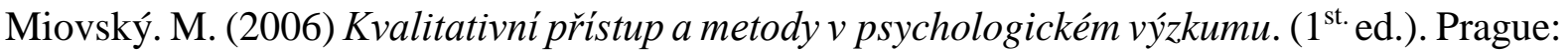
Grada.

Palmer, S., Torgerson, D. (1999) Economics Notes - Definitions of Efficiency. British Medical Journal. 318(7191), pp. 1136 - 1136.

Sabol, J., Tkáč, M. (2012) Multicriterial performance evaluation and Balanced Scorecard. Business Performance. In Závadský, J. (Ed.) Výkonnost’ podniku. (1 ${ }^{\text {st }}$ ed., pp. 95-106). Banská Bystrica: Výskumný ústav ekonomiky a manažmentu.

Skubičan, P. (2010) Priestorová multikriteriálna analýza pre podporu rozhodovania. In Kečkéšová, L. (Ed.) Mladí vedci 2010. (1 ${ }^{\text {st }}$ ed., pp. 462-470). Nitra: Univerzita Konštantína Filozofa.

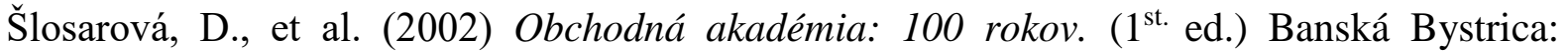
ERLAND BB.

Štefanišinová, N., Štrangfeldová, J. (2020) Proposal of indicators for measuring performance in the field of secondary education. Acta Aerarii Publici. 1(17), 68 - 92.

Štrangfeldová, J. (2013) Výdavky na zdravotníctvo v Slovenskej republike. (1 ${ }^{\text {st. }}$ ed.) Bratislava: Iura Edition.

Štrangfeldová, J., Štefanišinová, N., Hronec, Š., et al. (2018) Evaluation of Performance in Education - Value for Money. In Bod'a, M. (Ed.) Economic Theory and Practice 2017. $\left(1^{\text {st }}\right.$. ed., pp. 598-613). Banská Bystrica: Belianum. 